See discussions, stats, and author profiles for this publication at: https://www.researchgate.net/publication/319392777

\title{
What do consumers appreciate about on-demand economy workers?
}

Working Paper · August 2017

\section{CITATION}

1

1 author:

\section{Santiago Melián-González}

Universidad de Las Palmas de Gran Canaria

52 PUBLICATIONS 535 CITATIONS

SEE PROFILE

Some of the authors of this publication are also working on these related projects:

READS

244

Collaborative economy View project 


\title{
What do consumers appreciate about on-demand economy workers?
}

\author{
Santiago Melián-González \\ University Institute of Tourism and Sustainable Economic Development (TIDES) \\ University of Las Palmas de Gran Canaria \\ santiago.melian@ulpgc.es
}

Document version: June, 2018

The sharing economy is generating different kinds of debates. One of them refers to the labor facet of this digital-based economy, usually known as the on-demand economy, gig economy, or digital labor market. Media and relevant institutions have published different news articles and reports describing this new form of work. Working in the on-demand economy is considered to have both negative and positive features. The latter contemplate the on-demand economy as an opportunity for anyone who wants to earn income. Nevertheless, the literature in this field has been criticized for its high rhetoric, and more empirical evidence is required. Based on more than 6,000 consumer comments, this study analyzes what consumers value about the work provided through two gig economy platforms. Results show that being successful in the ondemand economy is not as easy as commonly stated because consumers clearly value professionalism and excellent services. This information can help workers and institutions to understand what kind of performance is expected in order to be successful in this new labor market.

\section{Keywords}

Sharing economy, gig economy, on-demand economy, digital labor market

\section{Introduction}

The reference section of this article shows that relevant institutions are both concerned and hopeful about the labor facet of the sharing economy (henceforth SE). The European Commission, European Parliament, International Labor Organization, OECD, US Department for Labor, and Unions have published several reports about this issue.

Although there are no official, ad hoc data about workers in the SE, there is evidence that their importance is growing (Codagnone et al., 2016; Katz and Krueger, 2016). In fact, several terms are used to refer to this labor market based on Internet platforms. The most 
frequent terms are gig economy, on-demand economy, digital labor markets, and collaborative labor markets. These terms will be used interchangeably throughout the rest of this article.

The on-demand economy fits what are considered alternative work arrangements (Katz and Krueger, 2016). The latter include temporary workers, temporary work agencies, outsourcing, offshoring, and independent contractors, all of which have increased in recent years (Codagnone et al., 2016; Katz and Krueger, 2016). There is evidence that the importance of on-demand economy workers is also rising. Based on a sample of 260,000 individuals in the US who earned income through SE platforms between 2012 and 2015, JPMorgan (2016a) found that year by year growth rates in monthly participation in gig economy platforms ranged from $300 \%$ to $400 \%$.

One characteristic of this digital labor marketplace is the great abundance of workers, which means that clients can easily find what they need. Furthermore, the possibility has been proposed that in digital labor markets a concentration of work assignments or superstar effect could exist (Codagnone et al., 2016). Thus, although registering in an on-demand platform is quick and easy, there is evidence that only a few of the registered workers earn income (De Groen et al., 2016; Gheorghe, 2015). In addition, in this marketplace, earnings tend to be sporadic, and getting enough income to make a living is an infrequent situation (JPMorgan, 2016b).

Because digital labor markets are abundant and competitive markets, it is interesting to know what consumers appreciate about experienced providers' performances. The current state of the literature on digital labor markets has been criticized for its rhetoric (Codagnone et al., 2016). Obtaining evidence from consumer assessments can be helpful for workers and institutions that consider the on-demand economy a possible source of earnings. The present study tackles this issue through a content analysis of the clients' comments on two different type of gig economy platforms. The article unfolds as follows. The first two sections define the SE and gig economy. Next, an explanation is provided about why it is considered an opportunity for workers. Then, the objective of the research is described, and the methodology is explained. Finally, the results are presented, and the conclusions and limitations are discussed.

\section{Sharing economy}

The SE involves different kinds of relationships between different types of agents based on Internet platforms. Due to this diversity, it is difficult to find a definition of SE that embraces all these possibilities. The first definitions (Bostman and Rogers, 2011) emphasized the idle resources that individuals share in exchange for other resources, money, or even nothing. Thus, 
initially, SE was not perceived as a work-related activity, but rather as a behavior driven mainly by the desire to share resources that were underutilized. Nevertheless, the SE developed, and some authors (Aloisi, 2015; Bostman, 2015; Eckhardt and Bardhi, 2015) and media (The Economist, 2013) stated that, in fact, some individuals were working or renting products using SE platforms. Therefore, SE involves both exchanges between individuals who do not pursue economic gain objectives (e.g, Couchsurfing or Peerby) and relationships that are clearly based on for-profit aims (e.g., Airbnb or Uber). Thus, a report published by the European Commission (2016b) distinguishes two main types of exchanges in the SE: social purpose and for-profit aimed. More recent SE definitions (European Commission, 2016a; Bulchand-Gidumal and Melián-González, 2016) try to reflect all of these nuances.

\section{Gig economy, on-demand economy, digital labor markets, collaborative labor markets}

In the literature, the terms included in the title of this section are used interchangeably to refer to the same phenomenon (Bock et al., 2016). Income earned by individuals in the SE draws on physical capital (e.g., Airbnb) or on labor (e.g., TaskRabbit or Uber) (Codagnone et al., 2016; Sundarajaran, 2014). The terms gig economy and on-demand economy were proposed to refer to the labor facet of the SE (Davis, 2015; Committee of the Regions, 2015; Frey, 2012; Slaughter, 2015). These names are based on the main characteristics attributed to the type of work that the on-demand economy promotes. Thus, for some authors, these characteristics are uncertainty, very short-term relationships, self-employed workers, high competition, strong dependence on consumer requests, and subordination to customer experience (Aloisi, 2015; Davis, 2015; De Groen et al., 2016; Friedman, 2014; Horton and Chilton, 2010; Sprague, 2015; Todolí-Signes, 2015).

Sundarajaran (2014) indicates that in the SE, labor mainly consists of providing professional services (e.g., Uber) and general-purpose labor (e.g, TaskRabbit). Codagnone et al. (2016) focused on what they call digital labor markets, in order to exclude digital markets mainly based on physical properties or goods components. According to the authors, digital labor markets consist of digital platforms that mediate and administer the relationship between the worker and the client. This market is two-sided: an online labor market and a mobile labor market. The former consists of work performed in a remote way (e.g., Upwork or Freelancer), and the latter refers to work that requires physical and localized delivery (e.g., Uber or TaskRabbit). The authors also classify on-demand economy work by the skill level required, from low- or mid-level skilled work to mid-level or highly skilled work. On both sides of the digital labor market, it is possible to find any type of work (low, medium or highly skilled), although in mobile labor markets, low and mid-level skilled work predominates. De Groen and Maselli (2016) use the 
term collaborative labor market, and they classify its work in the same way as Codagnone et al. (2016) do.

\section{Opportunity for workers}

It has been stated that the types of work that alternative work arrangements entail are a "necessary element of modern labor markets and they are unlikely to disappear" (Eurofound, 2015: 144). Digital labor markets' consequences for workers are far from clear. In fact, their effects can be considered both negative and positive (Codagnone et al., 2016). The unfavorable impact revolves around the precarious conditions and uncertainty that can characterize this type of work (Aloisi, 2015; Austrian Chamber of Labour et al., 2016; Schwartz, 2016; Todolí-Signes, 2015). At the same time, institutions and several authors find opportunities in digital labor markets. Thus, based on several reports (Committee of the Regions, 2015; European Commission, 2016a; European Commission 2016b), the European Commission assumes that digital labor markets may represent an opportunity for employment growth, flexible work, and additional income. According to the US Department for Labor (2016), digital labor markets offer new ways for people to monetize their existing assets and earn a living. In fact, workers participate in digital labor markets mainly for economic reasons (CIPD, 2017; Schmid-Drüner, 2016).

Codagnone et al., (2016) warn about the need to obtain empirical support for some of the consequences attributed to digital labor markets. Regarding the positive impact, the authors (2016: 6) mention that "they can increase the pool of employers and workers by removing barriers and reducing transaction costs, improving matching, increasing human capital specialization, with potential net welfare effects such as more efficient labor markets and increased employment". For De Groen and Maselli (2016), the on-demand economy may contribute to liberating some professional services and creating new jobs because it provides opportunities for workers to convert their time and skills into earnings. Similarly, Sundarajaran (2014) cites positive consequences such as lower transaction costs, new forms of production and exchange, and more opportunities for micro-entrepreneurship.

\section{Objective}

Working in digital labor markets is often described as a new form of work. In addition, platforms advertise a large number of available workers to provide the services that consumers may request. TaskRabbit mentions 30,000 taskers, Toursbylocals 1,979, Uber 160,000, Handy 5,000, and Helpy, 20,000. Nevertheless, research shows that few of the registered workers get work through digital platforms (De Groen et al., 2016; Gheorghe, 2015). Additionally, work does not 
come easily to workers because studies have shown that they spend eighteen minutes on unpaid searching and predatory activity for every hour of paid work (Berg, 2016).

Therefore, the digital labor market is highly competitive (Huws, 2015), and it has been suggested that workers should have specific competences to succeed in it (Bock et al., 2016). Because meeting client expectations is a recognized antecedent of consumer behaviors such as purchasing, word of mouth, and loyalty (Cronin et al., 2000; Zeithaml et al., 1996), the present study aims to find out what clients appreciate about services received from experienced workers in digital labor markets. To the best of my knowledge, there is no research about this issue. It can be helpful for workers to know what clients value about their performance, and these results can also be taken into consideration by educational institutions in order to guide and train future professionals based on client preferences.

\section{Methodology}

This research draws on data from two on-demand economy platforms: TaskRabbit and Trip4real. Both platforms are considered mobile labor markets because workers must be in a specific place when they perform their work. Recently, Trip4real was acquired by Airbnb, and so the Trip4real web site has disappeared. On TaskRabbit, consumers can find providers for multiple labor demands mainly focused on physical work such as minor home repairs, moving and packing, and furniture assembly. On Trip4real, workers were specialized in providing different types of tourism experiences in tourist destinations, such as routes, gastronomy, and sport activities. TaskRabbit is considered the main example of a general-purpose labor supply platform, and Trip4real fits better in the category of a professional service supply platform (Surandarajan, 2014) The former is often associated with low to mid-level skilled work, whereas the latter requires more complex skills. Both platforms are considered important examples of their activities (Isaac, 2015 and Noguera Vivo et al., 2014, respectively).

In January 2016, data from clients' opinions about workers who provided services through the two on-demand economy platforms were manually downloaded. Only workers with fifteen or more client opinions were considered. The aim of this criterion is similar to the one used in the research by Maselli and Fabo (2015), who considered only workers with more than one performed task. Imposing this fifteen rating criterion could significantly reduce the sample, but it also guarantees that all the cases finally chosen are workers with a minimum degree of experience and involvement with the on-demand economy activity. In addition to the first fifteen comments about each worker, any negative comment was also collected for the analysis. 
TaskRabbit's activity is mainly located in the US, and so we decided to download data from the main American cities in terms of population. After exploring the three main cities (New York, Chicago, and Los Angeles), we found that in the next five, Houston, Philadelphia, Phoenix, San Antonio, and San Diego, only seven, one, two, zero, and seven workers with more than fifteen reviews were available, respectively. Thus, we did not explore cities with smaller populations, with the exception of two cases. First, we decided to consider Boston because it is where the TaskRabbit offices are located, which could mean that the population is more familiar with the platform. We found enough workers (42) in this city who fulfilled the aforementioned requirement, and so they were included. Second, we also decided to explore the case of San Francisco because it was one of the first cities where TaskRabbit started to operate after Boston. In fact, the number of workers who met the selection criterion was also quite large in this city (43).

In the case of Trip4real, all the destinations where this platform operated were explored. In all, workers from sixteen destinations were included, although $80 \%$ of them belonged to seven cities, as shown in the next section.

The information downloaded was both quantitative (the rating by each client) and qualitative (the comments posted by clients along with each rating). Qualitative information was analyzed through the software AntConc versión 3.4.4. This software shows the frequency associated with each word included in the text to be analyzed. Furthermore, it supplies the particular phrase in which each word is found. Thus, in case of doubt, the context of the word can be read.

Because many different kinds of words are used to build phrases (i.e., conjunctions such as and, verbs such as was, or articles such as the), the content analysis focused on adjectives about the worker's performance or the worker's characteristics. For the clients' comments from each platform, three different researchers analyzed the words and their frequency, and they independently proposed different categories to classify the adjectives. Initial inter researcher agreement in the analyses of the TaskRabbit and Trip4real client comments was $62 \%$ and $83 \%$, respectively. After these results, researchers met, resolved any differences, and reached consensual classifications.

\section{Results}

Table 1 collects the total amount of workers found with fifteen or more ratings and their territorial distribution. In both platforms, there is a high concentration of workers in two cities: New York and Barcelona. 
Table 1. Workers on the platforms

\begin{tabular}{ll|ll}
\hline TaskRabbit & & Trip4real & \\
\hline Cities & Workers & Cities & Workers \\
\hline New York & $34.8 \%$ & Barcelona & $25.1 \%$ \\
Los Angeles & $16.9 \%$ & Lisbon & $12.0 \%$ \\
San Francisco & $14.8 \%$ & Paris & $10.9 \%$ \\
Boston & $14.5 \%$ & London & $11.4 \%$ \\
Chicago & $13.1 \%$ & Rome & $7.4 \%$ \\
Houston & $2.4 \%$ & Madrid & $7.4 \%$ \\
San Diego & $2.4 \%$ & Amsterdam & $5.7 \%$ \\
Phoenix & $.7 \%$ & Edinburgh & $4.6 \%$ \\
Philadelphia & $.3 \%$ & Seville & $3.4 \%$ \\
& & Girona & $3.4 \%$ \\
& & Berlin & $2.3 \%$ \\
& & Dublin & $1.7 \%$ \\
& & Zaragoza & $1.1 \%$ \\
& & Córdoba & $1.1 \%$ \\
& & Granada & $1.1 \%$ \\
& & Mallorca & $1.1 \%$ \\
$\mathrm{~N}$ & & & \\
\hline
\end{tabular}

In the case of TaskRabbit, the total amount of comments analyzed was 4,439 . These comments included the first fifteen opinions received for each worker and whatever additional negative comment that appeared in the worker profile. Positive comments according with the thumb up signal that the platform uses for this type of rating were 4,350 and negative comments with a thumb down signal were 89. Following the same criteria for the sample of Trip4real client comments, a total of 1,970 opinions were studied from Trip4real: 1,949 were positive, and 21 were negative, on a client satisfaction scale used by the platform that ranged from one (very satisfied) to five (very unsatisfied).

TaskRabbit's consumer comments had a total of 107,502 words. A total of 6,984 positive and 41 negative adjectives were found. The former were classified in two large groups. One includes 2,114 positive adjectives (30.27\%) about workers' attitudes toward consumers, interpersonal skills, behaviors or characteristics (e.g., helpful, friendly, polite, communicative, patient). The second group includes different types of positive qualifications regarding the worker and/or the quality of the work performed (4,870 adjectives; $69.73 \%)$. In this category, there are different ways to rate workers' performance. The most frequent (2033 adjectives; 29.11\%) consist of global perceptions about the worker's characteristics (e.g., professional, 
efficient, thorough, or knowledgeable). Next, (1290; 18.47\%) consumers highlighted the high level or excellence of the worker's performance (e.g., amazing, awesome, fantastic, or excellent). The next group of qualifications was more specific because they focused on the worker's promptness $(997 ; 14.28 \%)$. Less frequent were adjectives about workers' hard work, energy or enthusiasm (317; 4.54\%), their flexibility and resourcefulness $(107 ; 1.53 \%)$, or carefulness $(84 ; 1.20 \%)$, and intellectual characteristics such as creativity and intelligence (42; $0.60 \%)$.

In the case of Trip4real, the total number of words in the consumers' comments was 46,595 . Of them, 2,525 were positive adjectives, and sixteen were negative qualifications. The consumers' ratings on this platform were different from those of TaskRabbit. The group of adjectives related to the interpersonal facet of workers (e.g., friendly, helpful, kind) was also mentioned, but with less importance $(351 ; 13.90 \%)$. The most important set of positive qualifications $(1705 ; 67.52 \%)$ revolved around the great impression the activity had on clients (e.g., great, amazing, wonderful, excellent, fantastic). To a lesser extent (311; 12.32\%), consumers highlighted workers' knowledge (knowledgeable, thoroughly, expert), passion or enthusiasm (114; $4.52 \%)$, intellectual resources $(29 ; 1.15 \%)$, and promptness $(14 ; 0.55 \%)$.

On both platforms, negative comments mostly focused on workers' bad performance. Qualifications such as being awkward, cumbersome, unprofessional, unprepared, or unable, or ignoring questions, reflected the workers' inability to carry out their services according to clients' expectations.

\section{Conclusions}

Advocates of the sharing economy have emphasized that anyone with idle resources can participate in this economy. Results show that being successful in this particular digital labor market is more complex. Clients actually appreciate high performers and great services. In fact, in the gig economy, less than $10 \%$ of workers are students (Codagnone et al., 2016). These expectations coincide with the earning income motive given by gig workers when they are asked for their reasons for participating in digital labor markets.

Initially, the on-demand economy was approached as a unique and homogeneous marketplace. Recently, a segmentation was proposed, based, on the one hand, on where the work is performed and, on the other, on the level of skills required. In this regard, this study reflects that what can turn a worker into a high performer in the gig economy may depend to some extent on the type of digital labor market. On TaskRabbit, a platform mostly focused on physical tasks, consumers clearly appreciate professionalism and excellent client-oriented 
performance. Alternatively, in the case of Trip4real, a platform offering tourist experiences, consumers highlighted the great experience the workers were able to produce. Therefore, being successful in these digital labor markets requires different kinds of actions, which, at the same time, must be characterized by high performance.

Obviously, common appreciations about workers' performance were found. Thus, consumers of both platforms clearly value client-oriented worker behaviors. Whether work consists of moving furniture from a place to another, or guiding a tourist group in a particular cultural destination, consumers really appreciate friendly and helpful workers.

Findings suggest that before joining a digital labor market, workers should have the suitable skills and knowledge for the services they wish to provide. If they perform a service without the necessary skills, they can fail, and a negative client comment can be uploaded to the platform. The SE and on-demand economy relies heavily on consumers' opinions (SchmidDrüner, 2016), and unfavorable comments can seriously affect the probability of being requested.

Similarly, digital labor platforms should warn potential on-demand workers that they should have the skills that good performance demands. Digital labor markets are not suitable for amateurs, even though much of the SE rhetoric preaches the opposite. Furthermore, although the role of digital labor platforms in managing their suppliers is a complex issue (Codagnone et al., 2016; Schmid-Drüner, 2016), they could provide training opportunities to develop the suitable skills. In this regard, there are online labor markets (e.g., Upwork) that provide free tests so that workers can be aware of their skill levels. Additionally, digital labor market platforms compete with traditional labor markets for the same human resources. If traditional companies implement sophisticated human resource practices to attract and retain the best employees, on-demand economy platforms should do the same because their consumers value good professionals and services.

Finally, institutions that seek to improve individuals' employability could provide training programs that prepare individuals to show the skills that particular digital labor markets require. Up until now, this field has not been approached by these institutions, which mainly focus on the traditional labor market. 


\section{Limitations}

This research is based on two on-demand economy platforms, and so generalizations are not possible. In addition, the study only draws on client comments uploaded on platforms; therefore, it does not take into consideration clients who do not share their experiences.

\section{References}

Aloisi, A. 2015. "Commoditized Workers The Rising of On-Demand Work, A Case Study Research on a Set of Online Platforms and Apps. A Case Study Research on a Set of Online Platforms and Apps", available at: http://papers.ssrn.com/sol3/Papers.cfm?abstract_id=2637485 (accessed 20 February 2016).

Austrian Chamber of Labour et al. 2016. "Frankfurt Paper on Platform-Based Work", available at https://www.google.es/url?sa=t\&rct=i\&q=\&esrc=s\&source=web\&cd=1\&cad=rja\&uact=8\& ved=0ahUKEwiM9NXli7vSAhWB8RQKHUmvC6oQFggmMAA\&url=https\%3A\%2F\%2Fwww.i gmetall.de\%2Fdocs 20161214 Frankfurt Paper on Platform Based Work EN b939ef8 9f7e5f3a639cd6a1a930feffd8f55cecb.pdf\&usg=AFQjCNFux6DPFTrs79SGmcT2pq-Pw9J-7A (accessed 23 February 2017).

Berg, J. 2016. Income security in the on-demand economy: Findings and policy lessons from a survey of crowdworkers, International Labour Organization. Geneva. Available at: http://www.ilo.org/wcmsp5/groups/public/---ed protect/---protrav/--travail/documents/publication/wcms 479693.pdf, (accessed 20 February 2016).

Bock, A.K., Bontoux, L., Figueiredo do Nascimento, S. and Szczepanikova, A. 2016. "The future of the EU collaborative economy Using scenarios to explore future implications for employment", Publications Office of the European Union, available at: https://ec.europa.eu/jrc/en/publication/eur-scientific-and-technical-researchreports/future-eu-collaborative-economy-using-scenarios-explore-future-implicationsemployment (accessed 03 January 2017).

Botsman, R. and Rogers, R. 2011. What's mine is yours: how collaborative consumption is changing the way we live, Collins, London.

Bostman, R. 2015. "Can the Sharing Economy Provide Good Jobs?" The Wall Street Journal, available at: http://www.wsj.com/articles/can-the-sharing-economy-provide-good-jobs1431288393 (accessed 12 December 2015). 
Bulchand-Gidumal, J. and Melián-González, S. 2016. Una guía para entender la economía colaborativa, available at: https://www.amazon.es/entender-econom\%C3\%ADacolaborativa-clientes-consumidores-individuos-proveedores-ebook/dp/B01MRNC50W/.

Cheng, D. 2014. Reading between the lines: blueprints for a worker support infrastructure in the peer economy, Doctoral dissertation, Massachusetts Institute of Technology, available at: http://dspace.mit.edu/handle/1721.1/89953\#files-area (accessed 17 November 2015).

CIPD 2017. "To gig or not to gig? Stories from the modern economy", available at: https://www.cipd.co.uk/Images/to-gig-or-not-to-gig_2017-stories-from-the-moderneconomy_tcm18-18955.pdf (accessed 17 March 2017).

Codagnone, C., Abadie, F. and Biagi F. 2016. The Future of Work in the 'Sharing Economy'. Market Efficiency and Equitable Opportunities or Unfair Precarisation?, Institute for Prospective Technological Studies, JRC Science for Policy Report EUR 27913 EN, doi:10.2791/431485.

Committee of the Regions 2015. "The local and regional dimension of the sharing economy", available at: http://cor.europa.eu/en/activities/opinions/pages/opinionfactsheet.aspx?OpinionNumber=CDR\%202698/2015. (accessed 12 December 2015).

Cronin, J. J., Brady, M. K., and Hult, G. T. M. 2000. "Assessing the effects of quality, value, and customer satisfaction on consumer behavioral intentions in service environments", Journal of retailing 76 (2): 193-218.

Davis, G. F. 2015. "What Might Replace the Modern Corporation: Uberization and the Web Page Enterprise", Seattle University Law Review 39: 501-515.

De Groen, W. P. and Maselli, I. 2016. The Impact of the Collaborative Economy on the Labour Market, CEPS Special Report No.138, CEPS, Brussels, June.

De Groen, W.P., I. Maselli and B. Fabo 2016. The Digital Market for Local Services: A one night stand for workers?, CEPS Special Report No. 133, CEPS, Brussels, April.

Eckhardt, G. M. and Bardhi, F. 2015. "The sharing economy isn't about sharing at all”, Harvard Business Review, January 28, available at: http://hbr.org/2015/01/the-sharing-economyisnt-about-sharing-at-all (accessed 15 December 2015).

Eurofound 2016. New forms of employment, Luxembourg: Publications Office of the European Union, available at: https://www.eurofound.europa.eu/new-forms-of-employment (accessed 22 December 2015). 
European Commission, 2016a. A European agenda for the collaborative economy, available at http://ec.europa.eu/DocsRoom/documents/16881

European Commission, 2016b. Commission staff working document. Accompanying the document. Communication from the commission to the European Parliament, the Council, the European Economic and Social Committee and the Committee of the Regions - a European agenda for the collaborative economy, available at: http://ec.europa.eu/transparency/regdoc/?fuseaction=list\&coteld=1\&year=2016\&numbe $\underline{r=356 \& \text { version=ALL\&language }=e n}$ (accessed 22 July 2016).

European Commission 2016b). More than profit: a collaborative economy with a social purpose. Preliminary review of how collaborative economy models can help address social challenges in Europe and the characteristics of current activities, available at: http://ec.europa.eu/DocsRoom/documents/18443/ attachments/1/translations/en/renditions/native (accessed 16 December 2016).

Frey, T. 2012. "Workerless businesses-an explosive new trend: dancing with the inner entrepreneur", Journal of environmental health 75 3: 46-47.

Friedman, G. 2014. "Workers without employers: shadow corporations and the rise of the gig economy", Review of Keynesian Economics 2: 171-188.

Gheorghe, M. 2015. "State of Freelancing in IT and Future Trends", World Academy of Science, Engineering and Technology, International Journal of Social, Behavioral, Educational, Economic, Business and Industrial Engineering 9 (5): 1434-1438.

Horton, J. J. and Chilton. L. B. 2010). The Labor Economics of Paid Crowdsourcing, Proceedings of the 11th ACM conference on Electronic commerce.

Huws, U. 2015. "Capitalism and the Cybertariat: Contradictions of the Digital Economy", Monthly Review 66 (8): 42-57.

Isaac, E. 2015. "Innovative Clusters and New Work: A case study of TaskRabbit", Berkeley Roundtable on the International Economy, BBRIE Working Paper 2015-2, University of California at Berkeley, Berkeley, CA.

JPMorgan 2016a. "The Online Platform Economy: What is the growth trajectory?", available at: https://www.jpmorganchase.com/corporate/institute/document/ope-growthtrajectory.pdf (accessed 01 December 2016). 
JPMorgan 2016b. "Paychecks, Paydays, and the Online Platform Economy", available at: https://www.jpmorganchase.com/corporate/institute/document/jpmc-institute-volatility2-report.pdf. (accessed 01 December 2016).

Katz, L. F. and Krueger, A. B. 2016. "The rise and nature of alternative work arrangements in the United States, 1995-2015", National Bureau of Economic Research, No. w22667.

Maselli, I. and Fabo, B. 2015. Digital workers by design? An example from the on-demand economy, CEPS Working Document, available at http://www.ceps.eu.

Noguera Vivo, J. M., Martínez Sánchez, J., Nicolás Ojeda, M. Á., Pérez Escolar, M., Grandío Pérez, M. D. M., Hernández Gómez, F., and Sánchez Cobarro, P. D. H. 2014. Economía de la Participación, Fundación EOI. Madrid.

OECD 2016. "Working Party on Measurement and Analysis of the Digital Economy. New forms of work in the digital economy", OECD. Available at: http://www.oecd.org/.

Schmid-Drüner, M. 2016. "The situation of workers in the collaborative economy", European Parlament. October 2016, available at: http://www.europarl.europa.eu/RegData/etudes/IDAN/2016/587316/IPOL IDA(2016)587 316 EN.pdf.

The Economist 2013. "The rise of the sharing economy", available at: http://www.economist.com/news/leaders/21573104-internet-everything-hire-risesharing-economy (accessed 11 December 2015).

Slaughter, A.M. 2015. "The gig economy can actually be great for women", Wired, available at: http://www.wired.com/2015/10/unfinished-business-women-men-work-family (accessed 20 December 2016).

Sprague, R. 2015. "Worker (Mis) Classification in the Sharing Economy: Square Pegs Trying to Fit in Round Holes", Journal of Labor \& Employment Law 53, pp.1-23, available at: https://ssrn.com/abstract=2606600 or http://dx.doi.org/10.2139/ssrn.2606600 (accessed 11 December 2015).

Sundarajaran, A. 2014. "Peer-to-Peer Businesses and the Sharing (Collaborative) Economy: Overview, Economic Effects and Regulatory Issues. Written testimony for the hearing titled The Power of Connection: Peer to Peer Businesses, January", available at: http://smbiz.house.gov/ uploadedfiles/1-15-2014_revised_sundararajan_testimony.pdf 
Schwartz, D. B. 2016. "Working on the Boundaries of the Firm: Uncertainty and Labor Market Intermediaries in an Online Platform Economy", Working paper, Center for the Study of Social Organization, available at: https://www.princeton.edu/csso/working-papers/WP15$\underline{\text { Schwartz.pdf }}$

Todolí-Signes, A. 2015. "The End of the Subordinate Worker: Sharing Economy, On-Demand Economy, Crowdsourcing, Uber Economy and Other Ways of Outsourcing", available at: http://papers.ssrn.com/sol3/papers.cfm?abstract_id=2719772 (accessed 11 December 2015).

Torpey, E. and Hogan, A, 2016. "Working in a gig economy", Bureau of Labor Statistics, available at: https://www.bls.gov/careeroutlook/2016/article/what-is-the-gig-economy.htm

US Department for Labor 2016. "The Future of Work: Diving into the Data", available at: https://blog.dol.gov/2016/06/17/the-future-of-work-diving-into-the-data.

Zeithaml, V. A., Berry, L. L., and Parasuraman, A. 1996. "The behavioral consequences of service quality", The Journal of Marketing 60: 31-46. 